\title{
TEACHER TALK IN CLASSROOM INTERACTION IN TEACHING SPEAKING FOR THE FIRST GRADE STUDENTS AT SMA NEGERI 20 MEDAN
}

\begin{abstract}
AN ARTICLE
Submitted in Partial Fulfillment of the Requirements for the Degree of Sarjana Pendidikan
\end{abstract}

By

NUR AINI VILLY

Registration Number: 2132121038

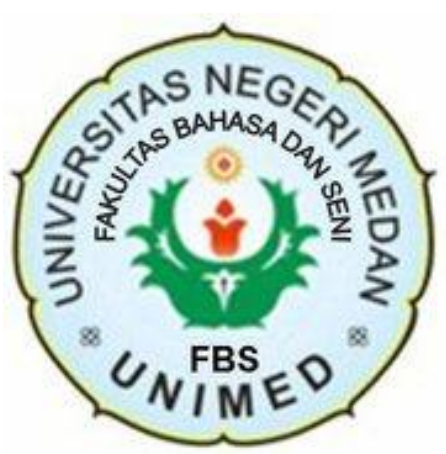

ENGLISH AND LITERATURE DEPARTMENT

FACULTY OF LANGUAGES AND ARTS STATE UNIVERSITY OF MEDAN 2018 
ARTIKEL

Disusun dan Diajukan oleh:

Nur Aini Villy

NIM. 2132121038

Telah diverifikasi dan dinyatakan memenuhi syarat untuk diunggah pada jurnal online

Medan, April 2018

Menyetujui

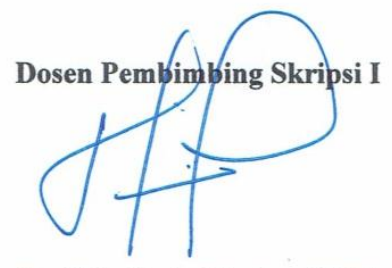

Dr. Siti Aisah Ginting, M.Pd. NIP. 195705211984032002

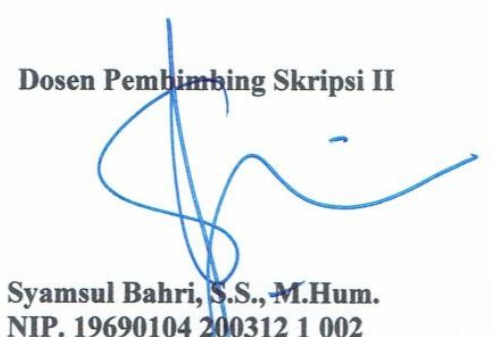

Ka. Program Studi

Pendidikan Bahasa Inggris

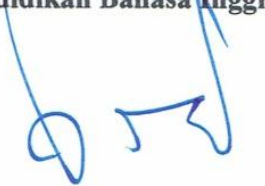

Nora Ronita Dewi, S.Pd., S.S., M.Hum.

NIP. 198005222008122003 


\title{
TEACHER TALK IN CLASSROOM INTERACTION IN TEACHING SPEAKING FOR THE FIRST GRADE STUDENTS AT SMA NEGERI 20 MEDAN
}

\author{
*Nur Aini Villy \\ ** Siti Aisah Ginting \\ **Syamsul Bahri
}

\begin{abstract}
This study aims at analyzing features of teacher talk in teaching speaking. The subject of this study were English Teacher and 40 students at first grade of SMA Negeri 20 Medan. The data were collected through the following: observation, and audio recording. In this research, the FLINT is used to identify the categories of teacher talk occur during the learning process. Moreover, this study is conducted in the form of descriptive qualitative research where the researcher as the non-participant observer on the classroom. From the data that has been taken, it is obtained that the categories of teacher talk used by the teacher in teaching speaking in the first grader of SMA Negeri 20 Medan are deals with feeling, praises or encourages, jokes, uses ideas of students, repeats students response verbatim, ask questions, gives information, corrects without rejection, give direction, criticizes student behavior, and Criticize student response. The finding of the study showed that there are eleven features of teacher talk occur in English classroom interaction and the dominant feature of teacher talk was ask questions (40.2\%). The feature of teacher talk which is dominantly used by the teacher help students more active in the class because the teacher gave the oppurtunity to the learners to deliver their ideas, and try their ability in speaking skill.
\end{abstract}

Keywords : Features of Teacher Talk, Foreign Language Interaction, Learning Process

\footnotetext{
*Graduate Status

$* *$ Lecturer Status
} 


\section{INTRODUCTION}

\section{Background of the Study}

The teacher's role make students feel interested in learning is very important. Teacher should know how to make their students learn well. Particularly in learning a language, a teacher should be able to stimulate the students to get involved in using the language in order to make the students get the optimal knowledge of the target language. Teachers also should consider the language used to interact with the students, which will encourage them to speak English.

Speaking is considered as a skill which is hard to be mastered. Because in speaking there are many elements of language which are acquired by the students such as vocabulary, grammar, pronunciation, etc. Luoma (2004) states that speaking in a foreign language students must master the sound system of language, have almost instant access to appropriate vocabulary and be able to put words clearly. In teaching speaking, the teacher should be able to use the language correctly, should be the example for the students to use English fluently without many hesitations and also has to make sure that utterance can be accepted well by the students.

One of the most important parts in teaching and learning process in the class is the classroom interaction. Classroom interaction is essential for the success of teaching and learning process. Classroom interaction refers to a technique consisting of objective and systematic of observation of the classroom events. 
Interaction simply means a communication which involves more than one person. The importance of interaction is explained by Brown (2007) through interaction, teacher and students exchange thoughts, feelings, and ideas resulting in a reciprocal effect on each other in the classroom. Thus, interaction in a language classroom is a process of learning language. English classroom interaction, especially verbal interaction is greatly expected to help student to increase their language store as they listen to or read authentic linguistic material, or even the output of what students follow in discussions, skits, joining yhe problem to solve the task, or dialogue. It means that increasing student English ability as the responsibility of the teacher in the classroom is through interaction, because the teacher will know what the students know and yet.

The happening of interaction is affected directly by the ways of teacher talk since it is the major spoken exposure to the students. There are some interpretations of teacher talk based on different sources. Szendroi (2010) states that teacher talk as the language typically used by the foreign language teachers in the process of teaching. In addition, Liu and Zhu (2012) define teacher talk is the major resources of comprehensible target language input the learners are likely to receive in the foreign language classroom teaching. From those definitions it can be concluded that teacher talk is a speech used by a teacher in order to deliver lessons in the class. Teacher talk is more important to language teaching as Walsh (2011) claims that teacher talk is more important to language classroom than any other classroom since in this context the language being used by teacher is not only the means of acquiring new knowledge, it is also the goal of the study. 
Teacher talk also has a special purpose in the language learning. Its purpose is to communicate with the students and to develop students' foreign language proficiency. Teacher talk is used to deliver the material, attract students' attention, and engage them to be active in teaching learning. Thus, teacher should know teacher talk well so that they can adjust her talk to make their sentences comprehensible for their students. The teacher talk is very possible to affect students' language acquisition since teacher is the one who speaks the most in the classroom. The proper use of teacher talk will have a positive effect on language learners' language output.

\section{REVIEW OF LITERATURE}

Nunan (1991) states teacher talk is of crucial importance, not only for the organization of the classroom but also for the processes of acquisition. It is important for the organization and management of the classroom because it is through language that teachers either succeed or fail in implementing their teaching plans. In terms of acquisition, teacher talk is important because it is probably the major source of comprehensible target language input the learner is likely to receive. Xiao-hui (2010) states that teacher talk is very important for both classroom teaching organization and students' language learning in the process of foreign language learning and second language acquisition, because teacher talk is an instrument of implementing teaching plan.

According to Moskowiz's FLINT ('Foreign Language INTeraction) analysis system in Brown (2001:177), teacher talk has eleven categories which enable to be analyzed in classroom interaction. Those eleven categories of teacher 
talk are divided into two kinds of influence; indirect and direct influence. Indirect influence divided into six categories, they are (1) Dealing with feelingss, (2) Praising or encourage, (3) Joking, (4) Using ideas of students, (5) Repeating Students Verbatim, (6) Asking Questions. While direct influence divided into five categories, they are : (1) Giving Information, (2) Correcting Without Rejection, (3) Giving Direction, (4) Criticizing students behaviour, and (5) Criticizing students Response.

Many definitions about speaking have been proposed by language experts. Spratt, Pulverness, and Willian (2005:21), define speaking is one of the four skills that is taught in language teaching. Together with writing, it is included as productive skill that involves using speech to express meaning to other people. Another definition comes from Cameron notions that speaking is the active use of language to express meanings so that other people can make sense of them Cameron (2001). To speak in the foreign language in order to share understandings with other people requires attention to precise details of the language. A speaker needs to find most appropriate words and the correct grammar to convey meaning accurately and precisely, and needs to organize the discourse so that a listener will understand. From some definitions, it can be concluded that speaking is the process of negotiating meaning trough verbal or non-verbal language that involves two or more people. Both the speaker and hearer have to react or give feedback to what they hear so that the communication can run well. 


\section{RESEARCH METHODOLOGY}

The research discusses classroom interaction study which focuses on teacher talk use Foreign Language INTeraction (FLINT) model. This study will be used qualitative research it means that the data will be collected is not in the form of number, but the data derived from interviews manuscripts, field note, personal document, record memos, and other official documents. Qualitative research usually takes place in naturally occurring situations, as constructed with exhibits control and manipulation of behavior and settings. (McMillan, 1992:9)

\section{Data and Source of Data}

The data will be the transcript of spoken interaction between teacher and students during the lesson in English classroom. The lessons are not intentionally prepared for the research, so it will be recorded under a natural classroom environment. The source of the data will be taken from the English classroom interaction between teacher and students in the tenth grade students of SMA Negeri 20 Medan

\section{Techniques for Collecting Data}

1. Observation is useful technique which provides evidence about additional information about topic being discussed. Yan (2006) states The objective of observation is to explain the situation being investigated activities, person or individual who are involved in an activity and the relationship among them. By doing observation, the researcher has the opportunity to know and understand the situation which occurs in teaching learning 
process, to see things that might be unconsciously missed, and to obtain information that might not be obtained from other technique.

2. Audio recording will be applied as the technique for capturing natural interaction in the classroom in detail. The researcher will be recorded the process of teaching and learning English that is aimed to get accurate information about the categories of the teacher talk occur during the language learning and the way teacher talk affects students' speaking ability.

Techniques for Analyzing Data

1. Transcribing the spoken data

2. Reducing the data

3. Data Coding

4. Classifying the data using the Foreign Language INTeraction (FLINT)

5. Drawing Conclusion from the response

\section{DATA AND DATA ANALYSIS}

The data of this study are utterances which is taken from the interactions between an English teacher and 40 students. This study is conducted to find out the feature of teacher talk by using Foreign Language INTeraction (FLINT) theory.

\section{FINDINGS}

From the analysis, it was found that the features of teacher talk used by the teacher during teaching learning process. There are 92 utterances which were uttered by English teacher. 
Table 4.1 Analysis Features of Teacher Talk

\begin{tabular}{|c|c|c|c|}
\hline No. & Features of Teacher Talk & Total $(\mathbf{F})$ & $\begin{array}{l}\text { Percentage } \\
P= \\
\frac{N}{F} x 100 \%\end{array}$ \\
\hline 1. & Dealing with feelingss & 5 & $5,4 \%$ \\
\hline 2. & Praising or encourage & 7 & $7,6 \%$ \\
\hline 3. & Joking & 3 & $3,2 \%$ \\
\hline 4. & Using ideas of students & 9 & $\mathbf{9 , 8 \%}$ \\
\hline 5. & Repeating students response verbatim & 3 & $3,2 \%$ \\
\hline 6. & Asking Questions & 37 & $40,2 \%$ \\
\hline 7. & Giving Information & 7 & $7,6 \%$ \\
\hline 8. & Corrects without rejection & 2 & $2,2 \%$ \\
\hline 9. & Giving Direction & 18 & $19,5 \%$ \\
\hline 10. & Criticizing student behavior & 1 & $1,1 \%$ \\
\hline 11. & Criticizing student response & - & \\
\hline & TOTAL & 92 & $100 \%$ \\
\hline
\end{tabular}

Table 4.1 above shows that the most dominant feature of teacher talk based on Foreign Language INTeraction (FLINT) model produced by English teacher. 


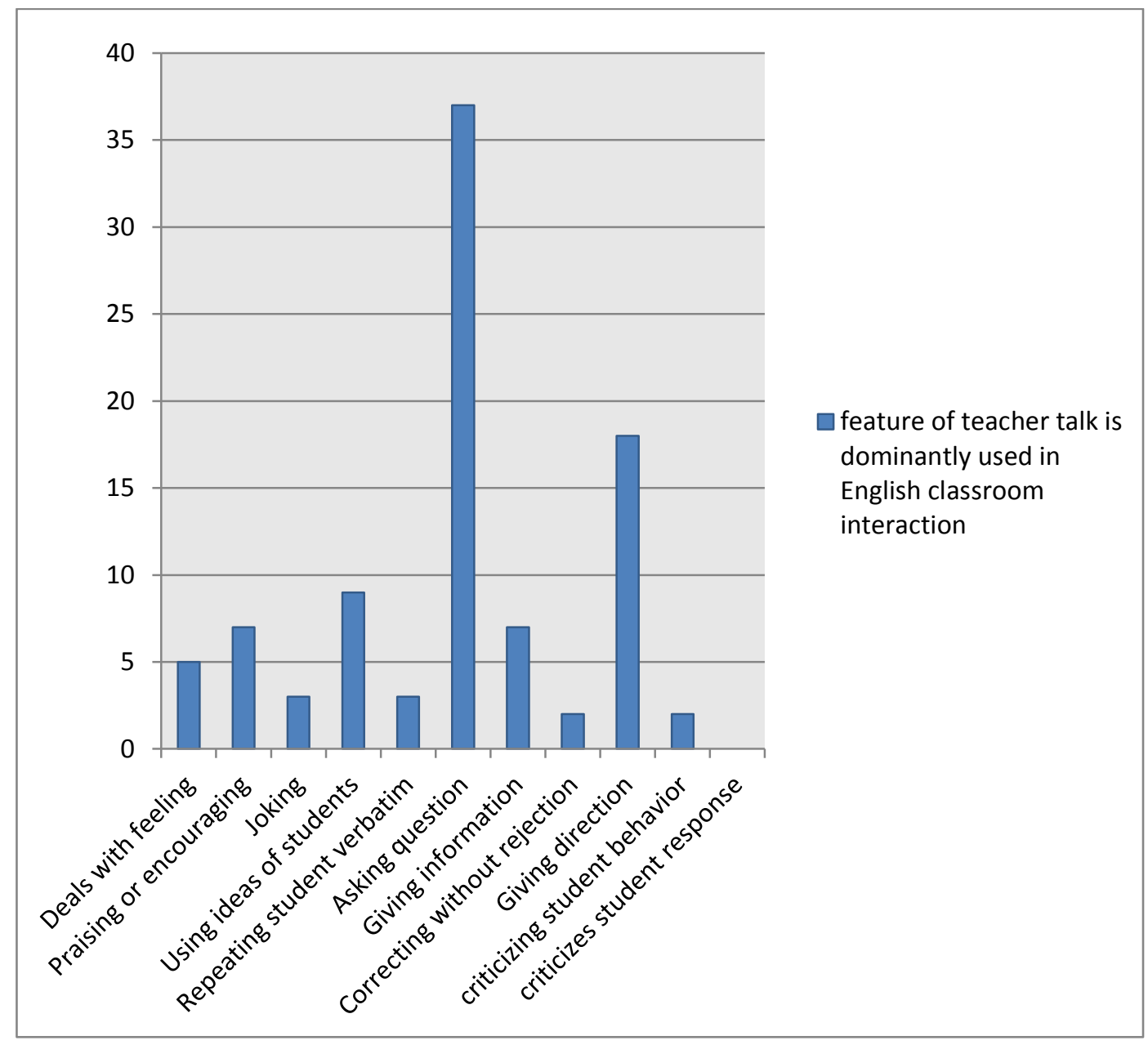

Figure 4.1 The percentage of feature of teacher talk by English Teacher

Figure 4.1 shows the the percentage of feature of teacher talk was the dominantly used in English classroom interaction. There were 92 utterances produced by the English teacher. The most dominantly used of teacher talk was asking question (39,8\%). In Asking questions, it is to stimulate to talk, to get students opinion or even though to get information from the students.

The second dominant feature of teacher talk is giving direction $(19,3 \%)$. It is the clear category that teachers perform to make a classroom activity. 
The third dominant feature of teacher talk is Using ideas of students $(9,7 \%)$. Teacher make some ways in expressing the appreciation, such clarify, using, interpret or summarize the ideas of students. Teacher can start a discussion based on students ideas by repharasing them but still recognized as students contribution

The fourth dominant feature of teacher talk is Giving Information (7,5\%). The teacher give the information about the topic in the teaching learning process.

The fifth dominant feature of teacher talk is praising or encouraging (7,5\%). Teacher activities motivate students to raise their motivation so they can find and develop their language skills. Motivation for students has done as well so the objectives of the lesson are achieve like the way it planned. Teacher is support students with praising, complementing, and tell the students that their ideas and works are valuable.

The sixth dominant feature of teacher talk is dealing with feelings $(5,3 \%)$. It is important because their experiences shape their minds, it helps teacher avoiding students trauma. The understanding from teacher and the right is of handling with students feeling is comfort the teacher-students interaction in the classroom

The seventh dominant feature of teacher talk is joking $(3,2 \%)$. Teacher helps the students to refresh their mind. It makes the students happy to study. By giving a joke, the students enjoy the teaching learning process.

The eighth dominant feature of teacher talk is repeating students response verbatim $(3,2 \%)$. It is a good way in teaching learning process. It makes the students comprehend about the subject. 
The ninth dominant feature of teacher talk is Correcting Without Rejection $(2,1 \%)$. The teacher points a student and asks them to give their opinions toward the topic discussed, then teacher corrects the mistake directly by saying it in the right pronounciation.

The tenth dominant feature of teacher talk is criticizing student behavior $(2,1 \%)$.

The eleventh dominant feature of teacher talk is Criticizing students Response.

\section{DISCUSSION}

Data are take from the students of the first grade at SMA NEGERI 20 Medan and reseacher observes an English teacher. At this page, researcher observed the teacher talk in classroom interaction. This research focuses on FLINT theory. There are two aspects of teacher talk that researcher observes based on FLINT theory, they are indirect influences and direct influences. The effectivess of teaching learning is based on teacher talk.

In teaching learning process, the teachers uses one of the categories of the FLINT theories, Asking Questions is one the most important thing in teacher talk. FLINT is a concept which states that teaching will be effective depending to a large on how directly and directly teacher influences the learners' behaviours. It makes the students interact with the teacher. In order to avoid the over use of teacher talk, teacher have to maximize student talk time and minimize teacher talk. Harmer (2000) points out that the best lesson are ones where student talk 
time is maximized. Getting students to speak to use the language their learning is a vital part of the teacher's job.

Based on the classroom observation result, it was found that the teacher talk is quite essential in the process of teaching and learning. By the presence of the teacher talk during the classroom activity, the students can be well involves and participated in learning. The teacher is the guider for the students in classroom so without a teacher, there is no teaching and learning process. It means that without the teacher talk then there is no learning, because a teacher without talk is useless.

\section{Conclusion and Suggestion}

The Conclusion

Based on the development result of the researcher in the fifth chapter, this research and development could be concluded that after analyzing the data, the researcher draws the conclusion that The feature of teacher talk in English class at SMA Negeri 20 Medan are the indirect teacher talk and direct teacher talk. The indirect influence are consist of dealing with feelings, praise/encourage, joke, use ideas of students, repeat students response verbatim, and Asking Questions. While direct influence are consist of giving information, Correcting Without Rejection, give directions, criticize students behavior, and criticize students' response. The total of these categories are 92 utterances. Asking Questions as the dominant feature of teacher talk. It shows that the feature of teacher talk which is dominantly used by the teacher helps the students to be more active in classroom interaction. 


\section{The Suggestion}

1. Suggestion to the other teachers

The English teacher can improve their teaching ways, especially to the talk time percentage, by too much talking the students have a little chance to practice their language, whereas language lesson is needed not just learns theoretically but more practically. The various of teacher's characteristic and the roles of teachers are expected to be able to motivate students to learn better and avoid boring impression in the classroom interaction, so that the learning process will be better.

2. Suggestion to the researchers

The reseacher suggests to other researcher to analyze teacher talk in English speaking activity because this study expects help and give the more information about teacher talk in classroom interaction.

\section{REFERENCES}

Allwright, D. \& K. M. Bailey. (1991). Focus on the Language Classroom: An Introduction to Classroom Research for Language Teacher. USA: Cambrige University Press.

Batko, A. (2004). When Bad Grammar Happens to Good People: How to Avoid Common Errors in English. Franklin Lakes, NJ: Career Press.

Brown, H. D. (2001). Teaching by Principles: An Interactive Approach to Language Pedagogy, Second Edition. San Fransisco: Longman

Brown, H. D. (2007). Principles of Language Learning and Teaching $\left(5^{\text {th }}\right.$ edition). USA: Pearson Education

Cameron, L. (2001). Teaching Language to Young Learners. Cambridge: Cambridge University Press.

Chaudron, C. (1998). Second Language Classroom: Research on Teaching and Learning. Cambridge: Cambridge University Press. 
Cook, V. (2000). Second Language Learning and Language Teaching (2ndEdition). Beijing: Foreign Language Teaching and search Press.

Creswell. (2009). Educational Research: Planning, Conducting, Evaluating Quantitative and Qualitative Research (3rd edition). New Jersey: Pearson Education International.

Harmer, J. (2000). How To Teach English. Beijing: Foreign Language Teaching and Research Press.

Harmer, J. (2001). The Practice of English Language Teaching (3rd Edition). London: Longman.

Kayi, H. Teaching Speaking: Activities to Promote Speaking in a Second Language. The Internet TESL Journal, Vol. XII, No. 11, May 2016.

Long, M. \& Sato, C. (1983). Classroom Foreigner Talk Discourse: Forms and Functions of Teachers $\square$ questions. In Seliger and Long (eds). Classroom Oriented research in Second Language Acquisition. Newbury House.

Luoma, S. (2004). Assessing Speaking. Cambridge: Cambridge University Press.

Mcmillan, J.H and Schumacher, S. (1992). Research in Education: A Conceptual Introduction. New York:Longman

Moskowitz, G., \& Hayman, J. L. (1976). Success Strategies of Inner-city Teacher: A year-long study. Journal of Educational Research.

Muhayyang, Maemuna. (2010). Lecturer and Student Talk in ClassroomInteraction: A Classroom Management Scheme. Unpublished Dissertation. Makassar: Hasanuddin University.

Nilasari. (2007). Teacher Talk in the Holistic English Class of Young Learners at Wima Kids Surabaya: Widya Mandala Catholic University

Nunan, D.(1991). Language Teaching Methodology: A Textbook for Teachers. Cambridge: Cambridge University Press.

Nunan, D.(1992).Research Methods in Language Learning. Cambridge: Cambridge University Press.

Nurhasanah, (2013). TheAnalysis of Teacher Talk and Learner Talk in Classroom Interaction (A Descriptive Study at 1st Grade of Senior High School in Bandung). Bandung: Education Univesity of Indonesia.

Purwanigara. (2016). Teacher and Student Talk in English Classroom Interaction of Vocational High School (A Naturalistic Study at SMK Negeri 2 Salatiga, Academic Year 2015/2016). Semarang: Sebelas Maret University. 
Rohmah, D. W. M. (2013). An Analysis of the Teacher Talk to Teach Speaking Descriptive Text to the Seventh Graders of SMPN 1 Sidoarjo.Surabaya: State University of Surabaya.

Rymes, B. (2008). Classroom discourse analysis: A tool for critical reflection. Cresskill, NJ: Hampton Press.

Spratt, Mary, Alan P, and Melanie W. (2005). TKT Course. Cambridge: Cambridge University Press.

Szendroi, I. (2010).Teacher Talk in the ESP Classroom-The Result of a Pilot Observation Study Conducted in the tourism Context. WoPaLP. Vol. 4. Budapest Business Schooll

Ur, P. (2000). A Course in Language Teaching: Practice and Theory. Beijing:Foreign Language Teaching and Research.

Turk, C. (2003). Effective Speaking: Communicating in Speech. London: Spon Press.

Walsh, S. (2011). Exploring classroom discourse: Language in action. London:Routledge.

Xiao-hui, (2010). Analysis Of Teacher Talk On The basic Of Relevance Theory. Vol. 6, No. 3, PP. 45.40

Yan, X. (2006). Teacher Talk and EFL in University Classroom. Chongqing Normal University \& Yangtze Normal University.

Yanfen, L. \& Zhao Yuqin. (2010). A Study of Teacher Talk in Interactions in English Classes. Chinese Journal of Applied Linguistics (Bimonthly) Vol. 33 No. 2. Harbin Institute of Technology. 